\title{
Mechanisms of learning in diet selection with reference to phytotoxicosis in herbivores
}

\author{
FREDERICK D. PROVENZA, JAMES A. PFISTER, AND CARL D. CHENEY
}

Provenza is associate professor, Range Science Department, Utah State University, Logan, Utah 84322-5230; Pfister is range scientist, USDA-ARS Poisonous Plant Research Lab., Logan, Utah 84321; Cheney is professor, Psychology Department, Utah State University, Logan, Utah 84322-2810.

\begin{abstract}
Our objective is to develop explanations for why herbivores ingest poisonous plants by first discussing how herbivores learn to select diets, by then considering mechanisms that enable herbivores to ingest phytotoxins, and by finally developing hypotheses about why herbivores overingest phytotoxins. Animals learn about foods through 2 interrelated systems: affective and cognitive. The affective system integrates the taste of food and its postingestive feedback; this system causes changes in the intake of food items, depending on whether the postingestive feedback is aversive or positive. The cognitive system integrates the odor and sight of food and its taste; animals use the senses of smell and sight to select or avoid specific food items. We further divide cognitive experiences into 3 categories: learning from mother, learning from conspecifics, and learning through trial and error. Physiological and conditional responses enhance the ability of animals to ingest phytotoxins. Physiological mechanisms include binding the com-
\end{abstract}

This work was supported by grants from Cooperative State Research Service (87-CRSR-2-3117) and the National Science Foundation (BSR-8614856). Journal paper No. 3956, Utah Agr. Exp. Sta., Utah State Univ., Logan 84322-4845. We dedicate this paper to the memory of our friend Dr. David F. Balph.

Manuscript accepted 28 May 1991. pound before it can exert its action, metabolizing the compound so it cannot exert its action, and tolerating the compound. Conditional responses complement physiological responses and further decrease herbivore susceptibility to toxins by preparing the animal for the effects of the toxin. Herbivores are likely to overingest poisonous plants when any of the aforementioned systems fail. For example, the affective system is likely to fail when phytotoxins circumvent the emetic system, when aversive postingestive consequences are delayed temporally and positive consequences during the delay are pronounced, and when toxicosis is accompanied by a change in environmental context. Likewise, cognitive systems are likely to fail when animals are unable to distinguish subtle molecular changes that render nontoxic plants toxic, when toxins in 2 or more plants interact, and when herbivores are unable to differentiate nutritious from toxic plants as a result of being placed in an unfamiliar environment. We conclude that $a$ thorough understanding of affective and cognitive systems, and the specific conditions under which these systems fail, will be necessary in order to understand why herbivores ingest foods that do them harm.

Key Words: taste, odor, sight, postingestive feedback, in utero, mother's milk, social learning, trial and error learning, preingestive experiences, detoxification, plant toxins, toxic plants, classical conditioning 
Assuming that herbivores have no desire to commit suicide, it is indeed curious that they overingest toxic plants (e.g., Fowler 1983, Cheeke and Shull 1985). To discover why herbivores ingest plants that do them harm, it is necessary to understand the challenges they face while foraging and the variables that control diet selection. Foraging environments present challenges to herbivores because nutrients and toxins vary temporally and spatially, not only among plant species, but within individual plants as well. Herbivores meet the challenge of selecting nutritious foods and avoiding toxic ones through learning (Provenza and Balph 1990). Our objective is to develop explanations for why herbivores fail to learn about phytotoxins under certain conditions. To do so, we first discuss how herbivores learn to select diets; we then consider mechanisms that enable herbivores to ingest toxins; and we conclude by developing hypotheses about why herbivores overingest phytotoxins.

\section{How Herbivores Learn to Select Diets}

Animals process information about foods through 2 interrelated systems: affective and cognitive (Garcia 1989). Taste plays a prominent role in both systems (Fig. 1). The affective system integrates

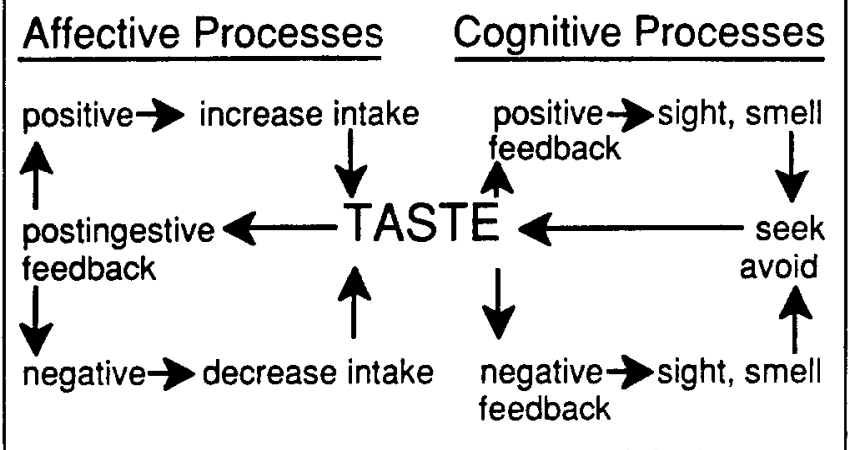

Fig. 1. Schematic representation of affective and cognitive processes in diet selection. The affective system begins with and integrates the taste of food with postingestive feedback. This system causes changes in the intake of food items that depend on whether the postingestive feedback is aversive or positive. The net result is incentive modification. The cognitive system integrates the odor and sight of food and its taste. Animals use the senses of smell and sight to detect subtle differences in foods and to select or avoid specific food items. The net result is behavior modification.

the taste of food with postingestive feedback. This system causes changes in the intake of food items that depend on whether the postingestive feedback is aversive or positive. The net result is incentive modification. On the other hand, the cognitive system integrates the odor and sight of food with its taste. Animals use the senses of smell and sight to differentiate among foods, and to select or avoid foods whose postingestive feedback is either positive or aversive. The net result is behavior modification. Cognitive experiences can be further divided to include use of the senses of sight and smell to learn from mother, learn from conspecifics, and learn through trial and error. Together, affective and cognitive processes provide flexibility for animals to maintain homeostasis as their nutritional needs and environmental conditions change (Provenza and Balph 1990).

The anatomical and physiological mechanisms underlying affective and cognitive systems have been fairly well established (Garcia et al. 1982, 1985; Castellucci 1985; Kupfermann 1985a,b). Taste afferents converge with visceral afferents in the solitary nucleus of the brain stem. The solitary nucleus has bidirectional connections with the area postrema which is thought to monitor nutrients and toxins directly in the blood stream and indirectly through visceral afferents (Garcia y Robertson and Garcia 1987). Taste and visceral afferents from these structures proceed to the limbic system, where the hypothalamus and related structures maintain homeostasis in the internal environment through the endocrine system, the autonomic nervous system, and the neural system concerned with motivation and drive (i.e., incentive modification). Higher cortical centers interact with the hypothalamus through the limbic system, and regulate the internal environment primarily by indirect action on the external environment (i.e., behavior modification). These alternative means of regulating the internal environment generally function in parallel. For example, the taste of food is adjusted according to that food's effect on the internal environment; on the basis, animals use thalamic and cortical mechanisms to select foods that are nutritious and avoid those that are toxic. In what follows, we review what is known or suspected about the abilities of herbivores to relate food flavors (taste plus odor) with postingestive feedback, and to differentiate among foods based on preingestive experiences.

\section{Affective Processes: Relating Foods with Postingestive Feedback Conditioned Food Aversions}

There are well supported theoretical arguments, and there is growing empirical evidence, that learned aversions are an important aspect of food selection in animals (Lindroth 1988, Provenza and Balph 1990). Indeed, learned food aversions have been demonstrated using a diverse array of compounds (Riley and Tuck 1985), in species as phylogenetically and ecologically diverse as garter snakes and tiger salamanders; quail, blackbirds, bluejays, and crows; rats, opossums, and mongooses; coyotes and timber wolves; goats, sheep, and cattle; olive baboons and humans (see reviews by Barker et al. 1977; Zahorik and Houpt 1977, 1981; Braveman and Bronstein 1985; Provenza and Balph 1988, 1990). Such observations suggest that learning is important in preventing fatal phytotoxicosis in nature.

Herbivores have physiological mechanisms to counter phytotoxins (see next section), and if the capacity of these detoxification systems is exceeded, mammals become ill and may die. However, mammals usually adjust intake to avoid intoxication. To do so, they must sample foods to determine when the concentrations of toxins change as a result of growth processes and previous herbivory (Bryant et al. 1983; Freeland and Janzen 1974; Westoby 1974, 1978). Sheep (Thorhallsdottir et al. 1987, Burritt and Provenza 1989a, du Toit et al. 1991b), goats (Provenza et al. 1990, Distel and Provenza 1991), and cattle (Pfister et al. 1990) sample foods and regulate their intake of nutritious plants that contain toxins. If toxicity decreases, the taste of the plant is no longer paired with aversive postingestive feedback. Any nutritional value the plant provides will cause intake of the plant to increase. In contrast, intake decreases as the toxicity of the plant increases.

Animals may regulate their intake of potentially toxic foods through aversive feedback from the emetic system of the midbrain and brainstem (i.e., area postrema), which is the same system responsible for nausea and vomiting in humans. The emetic system can be stimulated through many means, which include the cardiovascular system, cerebrospinal fluid, and visceral afferent nerves (Borison 1986, Davis et al. 1986, Grahame-Smith 1986, Kosten and Contreras 1989). Feedback from the emetic system need not involve any cognitive association or memory of aversive postingestive consequences. Thus, aversive feedback can occur even while the animal is anesthetized (Roll and Smith 1972, BermudezRattoni et al. 1988), deeply tranquilized (Forthman Quick 1984), or when its electrocortical activity is depressed (Buresova and Bures 1973, Davis and Bures 1972). It is imperative that the emetic system function with long temporal delays between food ingestion and postingestive feedback, and while animals sleep, because digestion 
and absorption can be slow processes and prolonged rest often follows a meal.

The senses of taste and smell play important, but somewhat different, roles in preventing toxicosis (Garcia and Holder 1985, Garcia et al. 1985, Garcia 1989). Animals must relate the taste of a food with aversive postingestive feedback before smell becomes important (Fig. 1). Once animals relate taste with internal malaise, the odor of the food can provide an indication of whether or not its chemical characteristics have changed. The different roles of odor and taste are further illustrated by the fact that a novel odor must be followed immediately by aversive feedback to produce strong odor aversion learning, but strong aversions to novel tastes can be conditioned even when aversive feedback is delayed up to 12 hours (Rozin 1976, Zahorik and Houpt 1981, Burritt and Provenza 1991a). When odor is combined with a distinctive taste, however, the conditioning associated with the odor is enhanced markedly. This effect, called potentiation, reflects the fact that a previously weak odor cue becomes a strong associative cue when it is presented in conjunction with taste (Rusiniak et al. 1979, 1982, Holder and Garcia).

\section{Conditioned Food Preferences}

Learned preferences based on positive postingestive feedback are undoubtedly important for herbivores, but there is little information concerning this hypothesis (Provenza and Balph 1987, 1990). Research concerning conditioned food preferences has involved primarily rats, and the results clearly indicate that rats eat more foods of nonnutritive flavors that are paired with: (1) calories (Messier and White 1984, Booth 1985, Mehiel and Bolles 1984, 1988, Simbayi et al. 1986); (2) recovery from nutritional deficiencies (Garcia et al. 1967, Zahorik et al. 1974); and (3) recovery from postingestive distress (Green and Garcia 1971, Sherman et al. 1983). Sheep develop a strong preference for nonnutritive flavors that are paired with glucose over nonnutritive flavors that are paired with the nonnutritive sweetener saccharine (Burritt and Provenza 1991b). This preference can best be attributed to positive postingestive feedback for 2 reasons. First, lambs exhibit equal preference for the glucose and the saccharin solutions on initial exposure; and second, lambs do not develop an aversion to the saccharine solution during conditioning. Lambs also develop strong preferences for poor quality foods (e.g., straw) paired with recovery from amino acid deficiency, and they develop aversions to diets deficient in various amino acids (Rogers and Egan 1975, Egan and Rogers 1978). Cattle also apparently develop a preference for supplemental protein blocks when ingesting forages low in protein (Provenza et al. 1983). Mechanisms such as those described below may enable herbivores to quickly associate specific foods with their postingestive feedback, and to form preferences for those that produce positive consequences.

In ruminants, byproducts of microbial fermentation such as volatile fatty acids and ammonia probably affect conditioned food preferences, as do pancreatic hormones such as insulin. Levels of portal and jugular blood metabolites, such as volatile fatty acids, $\beta$-hydroxybutyrate, and insulin, increase within 15 min after ruminants start eating (Thye et al. 1970, Evans et al. 1975, Chase et al. 1977, deJong 1981). Blood flow through the ruminal artery increases within 30 to $60 \mathrm{sec}$ after feeding begins, and peaks about 15 min later (Barnes et al. 1986). Although the onset and termination of meals do not appear to be controlled by volatile fatty acids (deJong 1985, Baile and McLaughlin 1987), receptors in the liver that respond to propionate may affect feeding behavior through afferent fibers between the hepatic plexus and the brain (Anil and Forbes 1980). The viscera of ruminants are richly supplied with sensory receptors and afferents to the brain (see review papers in Milligan et al. 1986), and neurally mediated signals from the liver affect conditioned flavor preferences and food intake in rats (Tor- doff and Friedman 1989). In addition, brain-gut hormones such as cholecystokinin, which affects food intake in rats (Dourish et al. 1989) and ruminants (deJong 1985, Baile and McLaughlin 1987), may also influence preference in rats (Mehile and Bolles 1988) and ruminants.

A single nutrient, compound, hormone, or organ is not likely to have a dominant role in producing conditioned food preferences, considering the variety of nutrients needed by animals. Rather, many mechanisms are likely to be involved, as with the control of food intake (deJong 1985) and conditioned food aversions (GrahameSmith 1986). Nor is there any reason to believe that herbivores should maximize the intake of any particular nutrient on a daily basis throughout life, given that animals can withstand wide departures from the normal average intake of energy-rich substances, nitrogen, various minerals, and vitamins (Booth 1985). Thus, it is not realistic to expect to consistently find correlations between various nutrients in plants and diet selection by herbivores (Westoby 1974, Arnold and Dudzinski 1978). Rather, homeostatic regulation needs only some increasing tendency, as a result of a deficit of some nutrient, to generate behavior to correct the disorder. Extreme states should cause herbivores to search for foods that rectify nutrient deficiencies and to form preferences for such foods.

\section{Cognitive Processes: Differentiating Among Foods Based on Preingestive Experiences}

Cognitive (preingestive) experiences involve the use of the senses of sight and smell to differentiate among foods (Fig. 1). Such experiences alone can influence the development of dietary habits when they involve use of the senses of sight and smell to: (1) learn from mother, (2) learn from conspecifics, and (3) learn through trial and error. Cognitive experiences interact with affective (postingestive) experiences to further determine diet selection in herbivores.

\section{Learning from Mother}

The inefficiency and risk of error associated with learning about foods solely through trial and error based on postingestive feedback could provide selective pressure for herbivores that feed in mixed-generation groups to rely on social learning. Through social learning, foraging information can be passed from experienced to inexperienced foragers, initially from mother to offspring. The effect of a mother on her offspring's dietary habits apparently begins in utero and may continue long after weaning.

Many compounds in plants quickly cross the placenta from mother to fetus (e.g., Smotherman and Robinson 1987, Keeler 1988), and animals may associate food flavors and gastrointestinal consequences while in utero (Hepper 1989). Thus, what is learned in utero and from mother's milk about flavors undoubtedly has both affective and cognitive elements. Rats form preferences for (Hepper 1988) and aversions to (Stickrod et al. 1982, Smotherman 1982) food flavors based on experiences in utero, and there are sensitive periods for learning in utero (Hill and Przekop 1988). The fetal taste system of lambs is functional during the last trimester of gestation (Bradley and Mistretta 1973), and fetal taste experiences may affect adult food preferences in herbivores such as goats, sheep, and cattle (Bradley and Mistretta 1973, Hill and Mistretta 1990, Nolte et al. 1991). Foods ingested by mother also influence the flavor of her milk (Bassette et al. 1986), which subsequently affects preferences for solid foods in rats (Galef and Sherry 1973, Capretta and Rawls 1974) and ruminants (Morrill and Dayton 1978, Nolte and Provenza 1992). Thus, the food preferences of young livestock are being conditioned before they ever begin to eat solid food.

As young herbivores begin to forage, learning efficiency is increased when they learn which foods to eat and which foods to avoid from their mothers. For example, lambs whose mothers have 
learned to avoid a food that causes postingestive distress learn to avoid that food more quickly than lambs reared without their mothers (Burritt and Provenza 1989a; Mirza and Provenza 1990, 1991a,b, see also Galef 1985a). Likewise, lambs learn to ingest foods preferred by their mothers more rapidly than lambs reared without their mothers (Mirza and Provenza 1990, 1991a,b; Thorhallsdottir et al. 1990a; Nolte et al. 1990). Such socially mediated feeding behavior fosters foraging traditions in social animals (Hunter and Milner 1963, Lynch 1987, Key and MacIver 1980, Roath and Krueger 1982).

\section{Learning from Conspecifics}

Social learning theory predicts that the most important models for a young animal are its mother and young companions (Bandura 1977). Clearly, mother has a marked effect on the establishment and persistence of her offspring's dietary habits (e.g., Key and MacIver 1980; Lynch et al. 1983; Green et al. 1984; Lynch 1987; Thorhallsdottir et al. 1990a,b; Nolte et al. 1990; Mirza and Provenza 1990, 1991a,b). As a young animal ages, however, it depends less on its mother for milk, and a mother apparently has less influence on her offspring's dietary habits (Hinch et al. 1987; Mirza and Provenza 1990, 1991a). Thus, as its mother's influence decreases, the influence of a young animal's young companions probably increases.

Young lambs markedly influenced one another's intake of food. For instance, averted lambs increase ingestion of $C$. montanus when foraging with nonaverted conspecifics on pastures $(10 \%$ of time spent ingesting $C$. montanus for averted lambs versus $19 \%$ of time for nonaverted lambs), even though ingestion of $C$. montanus was previously associated with the toxin lithium chloride in the averted lambs (Provenza and Burritt 1991). The results of Provenza and Burritt (1991) contrast sharply with results of Burritt and Provenza (1989b, 1990), where averted and nonaverted lambs grazed on separate pastures. In those studies, averted lambs spent much less time browsing $C$. montanus than nonaverted lambs (summer of $1987,0.2 \%$ to $0.4 \%$ versus $15 \%$ to $35 \%$ for averted and nonaverted lambs, respectively; summer of $1988,0 \%$ to $0.2 \%$ versus $3 \%$ to $26 \%$ for averted and nonaverted lambs, respectively). Social influences have also ameliorated aversions in sheep fed a pelleted diet in pens (Thorhallsdottir et al. 1990c), in cattle grazing on pastures (Lane et al. 1990, Ralphs and Olsen 1990), and in rats (Galef 1985b, 1986). The capacity of such interactions to ameliorate food aversions suggests that social influences are a major determinant of diet selection in social animals.

The effects of group composition (heterogeneous versus homogeneous for treatments) during conditioning also affected the use of C. montanus by lambs in the studies of Provenza and Burritt (1991). During conditioning, lambs in the heterogeneous groups were averted to $C$. montanus in the presence of lambs that were eating $C$. montanus. In the homogeneous groups, however, all lambs were averted to $C$. montanus during conditioning. After conditioning, when the lambs were foraging on pastures, lambs in the heterogeneous groups spent significantly more time browsing C. montanus than lambs in the homogeneous groups (e.g., trial 2, $11 \%$ versus $4 \%$; trial $3,17 \%$ versus $3 \%$; trial $4,43 \%$ versus $28 \%$ ).

\section{Learning through Trial and Error}

Learning from social models decreases the risk inherent in learning through trial and error if young animals remember foods and sample novel foods cautiously. Young herbivores can remember foods with either aversive (Distel and Provenza 1991, Lane et al. 1990, Burritt and Provenza 1990) or positive (Distel and Provenza 1990, Green et al. 1984, Squibb et al. 1990) postingestive consequences for at least 1 to 3 yr. To avoid overingesting potentially toxic foods, young animals should also be able to identify novel foods and they should sample them cautiously, which is character- istic of sheep and goats (Chapple and Lynch 1986; Chapple et al. 1987a,b; Thorhallsdottir et al. 1987, 1990a; Burritt and Provenza 1989a; Provenza et al. 1990). Animals that experience either unpleasant or pronounced positive postingestive consequences should attribute those consequences to novel rather than familiar foods, which is how sheep and goats behave after they receive as many as $\mathbf{4}$ familiar foods and 1 novel food, and a delay between ingestion and consequences of up to 6 hours (Burritt and Provenza 1989a, 1991a; Provenza et al. 1990). Herbivores must also sample foods, even familiar foods in familiar environments, because the nutrient content and toxicity of plants change frequently. When the toxicity of a plant diminishes, its flavor is no longer paired with aversive postingestive feedback, and any nutritional value the plant provides will cause intake of the plant to increase.

\section{How Herbivores Are Able to Ingest Phytotoxins}

Several mechanisms enhance the ability of animals to ingest phytotoxins. Physiological mechanisms include: (1) binding the compound before it can exert its action, (2) metabolizing the compound so it cannot exert its action, and (3) tolerating the compound (see reviews in this proceedings, Lindroth 1988). In addition, Siegel (1975) argues that conditioning is important. According to Siegel (1975), some ability to safely ingest phytotoxins results from an association of the effects of the compound with those environmental cues that reliably precede the effects. Thus, conditional responses complement physiological responses and further decrease herbivore susceptibility to toxins.

\section{Physiological Responses \\ Binding}

The ability to ingest potentially harmful phytochemicals could result from a systemic change within the animal which causes the compound to be bound before it exerts its action. For example, the size of parotid salivary glands, and their production of proline-rich proteins, increases in response to diets high in tannins in rats (Mehansho et al. 1983). Proline-rich salivary proteins apparently are a primary defense of rats against the adverse effects of tannins. They may serve the same function in some herbivores by forming tannin-protein complexes that pass inactively through the gastrointestinal tract (Robbins et al. 1987, Austin et al. 1989).

\section{Metabolizing}

Exposure to toxins may increase an animal's ability to metabolize the compound. In ruminants, the response involves organs such as the liver and rumen, as well as rumen microbes (Allison and Rasmussen 1991, Smith 1992). The liver can decrease the toxicity of compounds absorbed from the gastrointestinal tract by increasing or decreasing enzyme production, multiplication of specific organelles, or by increasing growth of the entire organ (SchulteHermann 1979). Phytochemicals such as terpenes and oxidized sterols induce enzymatic activity and liver growth (Wade et al. 1968, Wattenburg et al. 1976, Shulte-Hermann 1979). Pyrrolizidine alkaloids can be detoxified via ester hydrolysis, or activated via dehydrogenation to toxic pyrrolic metabolities (Mattock 1985). Ruminal metabolism may be the primary defense against some toxins, and the ability of rumen papillae and wall tissue to detoxify many compounds may exceed that of the liver (Smith 1986). In addition, microbial species change rapidly to enable ruminants to ingest various phytotoxins (Allison 1978, Allison and Rasmussen 1991). Rumen microbes reduce the toxicity of oxalates, cyanide, and pyrrolizidine alkaloids (Allison 1978, Smith 1986). Work with Leucaena leucocephala in Australia also illustrates that new microbial species can enhance detoxification by ruminants (Jones and Megarrity 1983, 1986), and genetic engineering may produce microorganisms capable of degrading specific plant toxins (C. Orpin, pers. comm.). 


\section{Tolerating}

The role of tolerance in diet selection by herbivores is unknown, but it may be important. Tolerance is defined operationally as either the reduced effect of the same dose of a toxin on subsequent ingestion, or a need to increase the dosage to maintain the same level of effect (Adler and Geller 1984). Research on tolerance emphasizes drugs like morphine, heroin, and alcohol, and involves the closely related phenomenon of dependence. Dependence is defined operationally as the series of events associated with chronic abuse of a drug, including the potential for abuse and the potential for behavioral and physical signs of abstinence. Tolerance and dependence are not inextricably linked (Adler and Geller 1984), thus an animal could develop a tolerance for a toxin without also developing a dependence on the toxin. Despite the lack of a clear understanding of the mechanisms responsible for tolerance and dependence, they are qualitatively different from those involving binding and metabolism.

\section{Variability in Physiological Responses}

Animals within a species vary in their ability to ingest phytotoxins. Variation exists among individuals in herbivores (Dove 1935, Arnold and Dudzinski 1978) and in humans (Weiss 1986), where a significant proportion of the population is generally hypersusceptible to a toxin. For example, some sheep fed a high (2.5X) level of Galega officinalis failed to show any clinical symptoms of toxicosis, while others were killed by a low (1.0X) dose (Keeler et al. 1988). Sheep show comparable variation in susceptibility to Verbesina encelioides (Keeler et al. 1992), and goats show similar variation in susceptibility to condensed tannins in Coleogyne ramosissima (Provenza et al. 1990). Differences in ability to bind, metabolize, and tolerate phytotoxins may help to explain variation in diet selection among individuals. Such variation forms the basis for natural selection, which can result in subpopulations of herbivores who differ in their abilities to ingest phytotoxins that occur in different environments within the range of species (Provenza and Balph 1990).

\section{Conditional Responses \\ Classical Conditioning}

Learning facilitates changes in behavior in response to changes in environmental conditions. One learning mechanism, that of classical conditioning elaborated by Pavlov (1927), involves responses that are generated reflexively. For example, a metronome elicits salivation in dogs when it is reliably followed by food. Such responses involve both unconditional and condition reflexes. An unconditional reflex consists of an unconditional stimulus (e.g., food) and the unconditional response (e.g., salivation) it evokes. A conditional reflex consists of a conditional stimulus (e.g., metronome) and the conditional response (e.g., salivation) it evokes. Such stimulus-response relationships pair previously neutral stimuli with the unconditional stimulus.

Some argue that the purpose of such conditioning is to prepare animals for the unconditional stimulus (Chance 1988). For example, when a dog responds to a metronome by salivating, the dog prepares to digest the food. The pairing of objects or events, whether accidental or intended, can lead to conditional responses that involve organs, glands, smooth muscles, and even immune processes (Ader and Cohen 1985). Odors, sights, and sounds associated with food play a similar role in daily life. Such conditional responses are influenced by at least 5 different factors including: (1) animal morphology, (2) animal physiology/biochemistry, (3) animal developmental history, (4) stimulating objects, and (5) environmental context (Kuo 1967).

\section{Classical Conditioning and Toxicosis}

Environmental stimuli associated with foraging could prepare herbivores to ingest phytotoxins. Pavlov (1927) viewed the admin- istration of a drug as a conditioning trial; the pharmacological assault constitutes the unconditional stimulus and the antecedent environmental cues serve as the conditional stimuli. The direction of conditional response to drugs is commonly opposite to that of the unconditional response, which serves to decrease the net effect of the drug over time. For example, the unconditional response to morphine decreases sensitivity to pain, while the conditional response to stimuli associated with morphine injection increases sensitivity to pain. Repeatedly presenting stimula associated with morphine administration effectively reverses morphine tolerance, which suggests the response is conditional (Siegel 1975). Likewise, conditioning moderates the normal effects of alcohol (Lightfoot 1980).

\section{Why Herbivores Ingest Phytotoxins}

We believe herbivores overingest toxic plants because affective and (or) cognitive systems fail. The following section concerns situations in which the affective system is likely to fail as a result of: (1) phytotoxins evading the emetic system, (2) interactions between aversive and positive postingestive consequences, or (3) changes in environmental context. In addition, we discuss how cognitive systems may fail when herbivores are unable to distinguish: (1) subtle molecular changes that render nontoxic plants toxic, (2) toxins in 2 or more plants, or (3) nutritious versus toxic plants in familiar or unfamiliar environments.

The division between affective and cognitive processes is somewhat artificial because they are so tightly coupled in foraging: when the affective system fails, the cognitive system is likely to play some role in the deficiency, and when the cognitive system fails, the affective system is likely to be responsible in part. Thus, our intent is not necessarily to draw a clear distinction between the 2 processes, but to focus attention on the system that appears to be most responsible for the inability of herbivores to learn to avoid phytotoxins. The examples illustrate how herbivores may inadvertently overingest phototoxins and are presented as working hypotheses.

\section{Affective Processes: Relating Foods with Postingestive Feedback Circumventing the Emetic System}

Herbivores may readily ingest some toxic plants and avoid some nontoxic plants, because not all toxic compounds cause aversive postingestive feedback and some nontoxic compounds produce aversive feedback (Garcia et al. 1985, Gamzu et al. 1985, Riley and Tuck 1985, Provenza et al. 1988). Any physiological, emotional, or perceptual event, or any chemical agent that affects the emetic system of the midbrain and brainstem presumably causes aversive feedback (Garcia 1989). Drugs such as lithium chloride, which affect the emetic system (Coil et al. 1978), cause strong food aversions but only weak place aversions in rats (Lett 1985). Conversely, compounds like gallamine, which causes neuromuscular blockage, or naloxone, which blocks the action of endogenous opiates on pain, cause strong place aversions but only weak food aversions in rats (Lett 1985). Likewise, drugs such as nembutal, strychnine, and cyanide affect the nervous system and metabolic processes, but not the emetic system, and thus do not cause conditioned food aversions (Garcia et al. 1985). Nor do animals necessarily learn to avoid foods that cause allergies, bloating, or lower intestinal discomfort, again because stimulation of the emetic system apparently is essential for producing conditioned food aversions (Pelchat et al. 1983, Garcia et al. 1985, Garcia 1989).

\section{Aversive versus Positive Consequences}

Research on conditioned preferences and aversions clearly suggests that the intake of food depends on postingestive feedback. Thus, the question arises: What happens when there are immediate positive but delayed aversive postingestive feedback, as when livestock ingest nutritious poisonous plants such as Delphinium bar- 
beyi? Small amounts of $D$. barbeyi enhance ruminal fermentation, forage intake, and digestion (Pfister et al. 1989), and consumption of $D$. barbey $i$ by cattle generally increases over a 2- to 4-day period before declining dramatically (Pfister et al. 1990). Alkaloids from $D$. barbeyi apparently accumulate in vivo and have maximum aversive effects in 2 to 4 day (J.D. Olsen, personal communication).

Such findings lead to the following hypothesis: the longer the delay between food ingestion and aversive postingestive feedback, and the higher the proportion of positive to aversive postingestive feedback during that time, the more likely livestock will sample and continue to ingest the food. This is consistent with the fact that an aversion to a food increases with severity of the illness, and decreases the longer the delay between food ingestion and illness (Garcia et al. 1974, Burritt and Provenza 1991a, duToit et al. 1991). Undoubtedly, any positive feed back during that time increases the preference and weakens the aversion for the food.

\section{Changing Environmental Context}

Environmental stimuli can elicit conditional responses to toxins in rats, and survival following heroin overdose improves if exposure to heroin occurs in the same environment (Siegel et al. 1982). Rats, with or without previous experience with heroin, were given a strong dose of heroin either in a familiar or a novel setting. The dose was lethal for $32 \%$ of the experienced rats in a familiar environment, $64 \%$ of the experienced rats in a unfamiliar environment, and $96 \%$ of the inexperienced rats in an unfamiliar environment. Siegel and Ellsworth (1986) cite a cancer patient who died when injected with morphine in a different room; the patient had tolerated the same dose when injected every 6 hours for 4 weeks in a familiar room. Likewise, social drinkers are more impaired when they drink ethanol at unusual times or in different settings (Dafters and Anderson 1982, Jones 1974, Shapiro and Nathan 1986, Siegel and Sdao-Jarvie 1986).

Given these findings, it is possible that herbivores may die from ingesting otherwise harmless amounts of plant toxins when environmental context changes. The relevant contextual cues in the case of herbivores may include anything from specific plants, to grazing cohorts, to foraging environments. Unfortunately, little is known about the role of context in toxicosis of herbivores because research most often focuses on specific independent variables, and neglects the larger and more diffuse but very relevant contextual aspects of treatment settings.

\section{Cognitive Processes: Differentiating Among Nutritious and Toxic Foods \\ Molecular Changes that Render Nontoxic Plants Toxic}

Herbivores have well-developed visual, olfactory, and gustatory faculties (Goatcher and Church 1970a,b; Arnold and Hill 1972; Arnold et al. 1980; Grovum and Chapman 1988), but in some cases they may not detect or respond to changes in plant chemistry associated with toxicity. For example, Burritt and Provenza (1989a) determined whether lambs would avoid a novel food (milo) even though the toxin lithium chloride $(\mathrm{LiCl})$ was administered to them through a familiar food (barley). Lambs first received barley treated with sodium chloride $(\mathrm{NaCl})$ for 3 weeks. In daily trials following the barley- $\mathrm{NaCl}$ exposure, lambs first received milo and then received barley treated with $\mathrm{LiCl}$. Lambs stopped consuming milo, but did not reduce barley consumption, even though the barley contained the $\mathrm{LiCl}$. Thus, the lambs either did not detect or did not respond to the differences between the $\mathrm{LiCl}-$ and $\mathrm{NaCl}$ treated barley. The ability of herbivores to detect subtle molecular changes that affect toxicity could be ascertained by using operant techniques in discrimination trials (Pfister et al. 1992).

Subtle changes in plant chemistry can render nontoxic plants, toxic, and in some instances herbivores may not detect or respond to such changes. Slight stereochemical differences in condensed such as Purshia tridentata less aversive than hrubs such as Coleogyne ramosissima (Clausen et al. 1990, Provenza et al. 1990). Teratogenicity of steroidal alkaloids is determined by the position of the nitrogen ( $\alpha$ vs. $\beta$ ) in the ring structure (Keeler 1984). The toxic alkaloid methyllycaconitine in Delphinium brownii becomes inactive when the aromatic ester group is removed (Aiyar et al. 1979). Centaurea spp., implicated in equine neurotoxicity, contain sesquiterpene lactones of which repin is 3 to 4 times more toxic than its $\mathrm{C}-17$ isomer subluteolide (Riopelle et al. 1991). The toxicity of Stypandra imbricata varies by region in Australia; toxic populations contain binaphtalene-tetrol named stypandrol, while nontoxic populations contain stypandrone, the oxidative form of the stypandrol precursor dianelliden (Colegate et al. 1991).

Concentrations of phytotoxins can change dramatically within hours as a result of diurnal fluctuations (Fairbain and Suwal 1961), or within minutes due to environmental changes such as rainfall (O'Dowd and Edgar 1989). Moreover, toxicity can change rapidly even though the concentration of a class of compounds like alkaloids does not. When individual diterpenoid alkaloids of Delphinium barbeyi change, apparently in response to rainfall, cattle consume more of the plant and mortality increases, although rainfall has not yet been linked directly with larkspur ingestion (Pfister et al. 1988a,b). Further, the proportions of individual pyrrolizidine alkaloids shift rapidly, and also vacillate between the nontoxic $\mathrm{N}$-oxide form and the toxic free-base forms (Mattock 1985, O'Dowd and Edgar 1989). Pyrrolizidine alkaloids change rapidly from the tertiary to the $\mathrm{N}$-oxide form as the seeds of Crotalaria scassellatii develop (Toppel et al. 1988).

\section{Toxins in 2 or More Plant Species}

It may be difficult for herbivores to associate toxicity with a specific food when the same toxin exists in more than 1 food, or when 2 or more compounds in different foods interact to cause toxicity. For instance, goats and deer ingest many plant species that are high in tannins (e.g., Provenza and Malechek 1984, Robbins et al. 1987, Provenza et al. 1990); how they limit intake of tannins under such conditions is unknown. Herbivores also encounter synergistic effects. Research is needed to determine the specific conditions under which toxicosis is likely to occur when the same toxin exists in more than 1 food, or 2 or more compounds in different foods interact to cause toxicity. For instance, sheep that consume Cicuta spp. may then be more susceptible to the compounds in Verbesina encelioides (Keeler et al. 1992). Various Astragalus and Oxytropis species contain toxic nitro compounds (miserotoxins) and selenium, which have synergistic effects on toxicity (Williams 1989). Sheep that consume Artemisia nova before Tetradymia glabrata are predisposed to photosensitization (Johnson 1974a,b). Photosensitization is not likely to cause a food aversion because the consequences do not involve the emetic system, but the hepatic dysfunction associated with ingesting these 2 plant species might cause a conditioned food aversion.

Under some circumstances, animals can learn to ingest plants that will minimize the effects of 1 or more toxins. To do so, herbivores need only associate aversive consequences with 1 of the plants containing toxic compounds. For instance, goats can detect differences in condensed tannin concentrations in different plant parts, and reduce intake of either or both plant parts to limit overall intake of condensed tannins (Provenza and Malechek 1984, Provenza et al. 1990, Distel and Provenza 1991). In addition, mice allowed to chose between a tannin-containing and a saponincontaining food ingest an amount of each such that toxic effects are minimized (Freeland et al. 1985). Toxicity occurs when mice are forced to consume a diet containing predetermined proportions of both compounds. 


\section{Nutritious versus Toxic Plants in Familiar or Unfamiliar} Environments

Experience early in life may affect consumption of poisonous plants during adulthood. A mother that avoids poisonous plants during gestation, lactation, and when her offspring are learning to forage, may teach the young to avoid the plants (Thorhallsdottir et al. 1990b; Mirza and Provenza 1990, 1991a,b). The opposite behavior by the mother may predispose her offspring to ingest the plants. Rats prenatally exposed to alcohol voluntarily consume more alcohol as adults (Molina et al. 1987). Livestock exposed during gestation to putative addicting plants, such as Astragalus and Oxytropis, may respond similarly. Young livestock also prefer solid foods whose flavors were in mother's milk (Morrill and Dayton 1978; Nolte and Provenza 1972), and may be predisposed to eat poisonous plants whose flavors are transferred through her milk (Panter and James 1990). Social models influence food ingestion by young livestock (Chapple et al. 1987b; Thorhallsdottir et al. 1990a,b,c; Nolte et al. 1990; Mirza and Provenza 1990, 199 la,b), and young animals are probably predisposed to ingest toxic plants preferred by the mothers. Conspecifics can cause animals to ingest foods that have been paired with toxicity (Lane et al. 1990, Thorhallsdottir et al. 1990c, Provenza and Burritt 1991). Young animals are apparently more susceptible to social influences than older animals, and the fewer alternative forages available, the more likely herbivores will ingest harmful foods ingested by conspecifics (Thorhallsdottir et al. 1990c).

Herbivores moved to an unfamiliar environment are apparently more prone to suffer from malnutrition and to ingest poisonous plants than those feeding in a familiar environment (Provenza et al. 1988, Provenza and Balph 1990). This could be due to enhanced effect of a toxin caused by a change in context, and (or) inability of herbivores to detoxify compounds in the new environment. In addition, it may be difficult for herbivores moved to a new environment to differentiate nutritious from toxic foods because all foods are novel (Burritt and Provenza 1989a). Animals moved to unfamiliar environments often develop aversions to toxic plants, but many die in the process. Ninety percent of the naive goats introduced into pastures containing Eupatorium rugosum died during the first 2 weeks of grazing, but survivors learned to avoid the plant (J. Reagor pers. comm.). Sheep in South Africa eat Senecio spp. for the first 3 days in an unfamiliar pasture, but then refuse to eat Senecio spp. even if starving (Kellerman 1987). Ranchers in South Africa give cattle, by gavage, a sublethal preparation of Homeria pallida to prevent deaths (Strydom and Joubert 1983), and report that only naive or extremely hungry animals eat the plant. Naive animals given a preparation of $H$. pallida, or untreated animals that survive beyond 4 days of grazing pastures containing $\boldsymbol{H}$. pallida, learn to avoid the plant (Strydom and Joubert 1983). Many cattle deaths caused by Delphinium barbeyi occur within 10 to 14 days after cattle enter a new pasture; survivors may learn to avoid ingesting a lethal dose (Olsen and Ralphs 1986).

\section{Conclusions}

Our hypothesis is that herbivores overingest toxic plants because affective and cognitive systems fail under certain conditions. Our understanding of affective and cognitive systems in herbivores is limited, as is our understanding of the specific conditions under which these systems fail. Thus, we believe that researchers face 2 challenges. First, we need to thoroughly understand how affective and cognitive processes affect diet selection. This paper offers a conceptual framework in which to study these processes. Second, we must use our understanding of affective and cognitive processes to investigate why herbivores ingest specific poisonous plants. Careful experimental analysis will clarify the nature, and lead to the prevention, of intake of poisonous plants by herbivores.

\section{Literature Cited}

Ader, R., and N. Cohen. 1985. CNS-immune system interactions: Conditioning phenomena. Behav. Brain Sci. 8:379-426.

Adler, M.W., and E.B. Geller. 1984. Contributions of neuropharmacology to understanding mechanisms of tolerance and dependence. p. 27-38. In: C.W. Sharp (ed.), Mechanisms of tolerance and dependence. NIDA Res. Monog. 54. Rockville.

Aiyar, V.N., M.H. Benn, T. Hanna, J. Jacyno, S.H. Roth, and J.L. Wilkins. 1979. The principle toxin of Delphinium brownii Rydb., and its mode of action. Experientia 35:1367-1368.

Allison, M.J. 1978. The role of ruminal microbes in the metabolism of toxic constituents from plants. p. 101-120. In: R.F. Keeler, K.R. Van Kampen, and L.F. James (eds.), Effects of poisonous plants on livestock. Academic Press, New York.

Allison, M.J., and M.A. Rasmussen. 1991. The potential for plant detoxification through manipulation of the rumen fermentation. p. 367-376. In: L.F. James, R.F. Keeler, E.M. Bailey, R.R. Cheeke, and M.P. Hegarty (eds.), Poisonous plants. Iowa State Univ. Press, Ames.

Anil, M.H., and J.M. Forbes. 1980. Feeding in sheep during intraportal infusions of short-chain fatty acids and the effect of liver denervation. $J$. Physiol. 298:407-414.

Arnold, G.W., and J.L. Hill. 1972. Chemical factors affecting selection of food plants by ruminants. p. 71-101. In: J.B. Harborne (ed.), Phytochemical ecology. Academic Press, London.

Arnold, G.W., and M.L. Dudzinski. 1978. Ethology of free-ranging domestic animals. Elsevier/North Holland, New York.

Arnold, G.W., E.S. deBoer, and C.A.P. Boundy. 1980. The influence of odor and taste on the food preferences and food intake of sheep. Aust. J. Agr. Res. 31:571-586.

Austin, P.J., L.A. Suchar, C.T. Robbins, and A.E. Hagerman. 1989. Tannin-binding proteins in the saliva of deer and their absence in the saliva of sheep and cattle. J. Chem. Ecol. 15:1335-1347.

Baile, C.A., and C.L. MeLaughlin. 1987. Mechanisms controlling feed intake in ruminants: a review. J. Anim. Sci. 64:915-922.

Bandura, A. 1977. Social learning theory. Prentice-Hall, Englewood Cliffs.

Barker, L.M., M.R. Best, and M. Domjan. (eds.). 1977. Learning mechanisms in food selection. Baylor Univ. Press, Waco.

Barnes, R.J., R.S. Comline, and A. Dobson. 1986. The control of splanchinic blood flow. p. 41-59. In: L.P. Milligan, W.L. Grovum, and A. Dobson (eds.), Control of digestion and metabolism in ruminants. Prentice Hall, Englewood Cliffs.

Bassette, R., D.Y.C. Fung, and V.R. Mantha. 1986. Off-flavors in milk. CRC Crit. Rev. Food Sci. Nutr. 24:1-52.

Bermudez-Rattoni, F., D.L. Forthman Quick, M.A. Sanchez, J.L. Perez, and J. Garcia. 1988. Odor and taste aversions conditioned in anesthetized rats. Behav. Neurosci. 102:726-732.

Booth, D.A. 1985. Food conditioned eating preferences and aversions with interoceptive elements: conditioned appetites and satieties. p. 22-41. In: N.S. Braveman and P. Bronstein (eds.), Experimental assessments and clinical applications of conditioned food aversions. New York Acad. Sci., New York.

Borison, H.L. 1986. Anatomy and physiology of the chemoreceptor trigger zone and area postrema. p. 10-17. In: C.J. Davis, G.V. Lake-Bakaar, and D.G. Grahame-Smith (eds.), Nausea and vomiting: mechanisms and treatment. Springer-Verlag, New York.

Bradley, R.M., and C.M. Mistretta. 1973. The gustatory sense in foetal sheep during the last third of gestation. J. Physiol. 231:271-282.

Braveman, N.S., and P. Bronstein (eds.). 1985. Experimental assessment and clinical applications of conditioned food aversions. New York Acad. Sci., New York.

Bryant, J.P., F.S. Chapin III, and D.R. Klein. 1983. Carbon/nutrient balance of boreal plants in relation to vertebrate herbivory. Oikos 40:357-68.

Buresova, O., and J. Bures. 1973. Cortical and subcortical components of the conditioned saccharin aversion. Physiol. Behav. 11:435-439.

Burritt, E.A., and F.D. Provenza. 1989a. Food aversion learning: ability of lambs to distinguish safe from harmful foods. J. Anim. Sci. 67:1732-1739.

Burritt, E.A., and Provenza, F.D. 1989b. Food aversion learning: conditioning lambs to avoid a palatable shrub (Cercocarpus montanus). J. Anim. Sci. 67:650-653.

Burritt, E.A., and F.D. Provenza. 1990. Food aversion learning in sheep: persistence of conditioned taste aversions to palatable shrubs (Cercocarpus montanus and Amelanchier alnifolia). J. Anim. Sci. 68:1003-1007. 
Burritt, E.A., and F.D. Provenza. 1991a. Ability of lambs to learn with a delay between food ingestion and consequences given meals containing novel and familiar foods. Appl. Anim. Behav. Sci. (In press).

Burritt, E.A., and F.D. Provenza. 1991b. Lambs form preferences for non-nutritive flavors paired with glucose. J. Anim. Sci. (In press).

Capretta, P.J., and L.H. Rawls. 1974. Establishment of a flavor preference in rats: importance of nursing and weaning experience. J. Comp. Physiol. Psychol. 88:670-673.

Castellucel, V.F. 1985. The chemical senses: taste and smell. p. 409-425. In: E.R. Kandel and J.H. Schwartz (eds.), Principles of neural science. Elsevier, New York.

Chance, P. 1988. Learning and behavior. Wadsworth, Belmont.

Chappel, R.S., and J.J. Lynch. 1986. Behavioral factors modifying acceptance of supplementary foods by sheep. Res. Develop. Agr. 3:113-120.

Chappel, R.S., M. Wodxicka-Tomaszewska, and J.J. Lynch. 1987a. The learning behavior of sheep when introduced to wheat. I. Wheat acceptance by sheep and the effect of trough familiarity. Appl. Anim. Behav. Sci. 18:157-162.

Chappel, R.S., M. Wodzicka-Tomaszewska, and J.J. Lynch 1987b. The learning behavior of sheep when introduced to wheat. II. Social transmission of wheat feeding and the role of the senses. Appl. Anim. Behav. Sci. 18:163-172.

Chase, L.E., P.J. Wangeness, J.F. Kavanaugh, L.C. Griel, Jr., and J.H. Gahagan. 1977. Changes in portal blood metabolities and insulin with feeding steers twice daily. J. Dairy Sci. 60:403-409.

Cheeke, P.R., and L.R. Shull. 1985. Natural toxicants in feeds and poisonous plants. AVI Publ. Co., Westport.

Clausen, T.P., F.D. Provenza, E.A. Burritt, J.P. Bryant, and P.B. Reichardt. 1990. Ecological implications of condensed tannin structure: a case study. J. Chem. Ecol. 16:2381-2392.

Coil, J.D., W.G. Hankins, D.J. Jenden, and J. Garcia. 1978. The attenuation of a specific cue-to-consequence association by antiemetic agents. Psychopharmacology 56:21-25.

Colegate, S.M., P.R. Dorling, and C.R. Huxtable. 1991. Stypandra imbricata (blindgrass) toxicity: chemistry, biosynthesis and chemotaxonomy. p. 459-463, In: L.F. James, R.F. Keeler, E.M. Bailey, P.R. Cheeke, and M.P. Hegarty (eds.), Poisonous plants. Iowa State Univ. Press, Ames.

Dafters, R., and G. Anderson. 1982. Conditional tolerance to the tachycardia effect of ethanol in humans. Psychopharmacology 78:365-367.

Davis, C.J., R.K. Harding, R.A. Leslie, and P.L.R. Andrews. 1986. The organization of vomiting as a protective reflex: a commentary on the first day's discussion. p. 65-75. In: C.J. Davis, G.V. Lake-Bakaar, and D.G. Grahame-Smith (eds.), Nausea and vomiting: mechanisms and treatment. Springer-Verlag, New York.

Davis, J.L., and J. Bures. 1972. Disruption of saccharin-aversion learning in rats by cortical spreading depression in the CS-US interval. J. Comp. Physiol. Psychol. 80:398-402.

deJong, A. 1981. The effect of feed intake on nutrient and hormone levels in jugular and portal blood in goats. J. Agr. Sci. Camb. 96:643-657.

deJong, A. 1985. The role of metabolites and hormones as feedbacks in the control of food intake in ruminants. p. 459-478. In: L.P. Milligan, W.L. Grovum, and A. Dobson (eds.), Control of digestion and metabolism in ruminants. Prentice-Hall, Englewood Cliffs.

Distel, R.A., and F.D. Provenza. 1991. Experience early in life affects voluntary intake of blackbrush by goats. J. Chem. Ecol. 17:431-450.

Dourish, C.T., W. Rycroft, and S.D. Iversen. 1989. Postponement of satiety by blockade of brain cholecystokinin (CCK-B) receptors. Science 245:1509-1511.

Dove, F.W. 1935. A study of individuality in the nutritive instincts and of the causes and effects of variations in the selection of food. Amer. Natur. 69:469-544.

duToit, J.T., F.D. Provenza, and A.S. Nastis. 1991. Conditioned food aversions: How sick must a ruminant get before it detects toxicity in foods? Appl. Anim. Behav. Sci. 30:35-46.

Egan, A.R., and Q.R. Rogers. 1978. Effects of amino acid imbalance on roughage intake of ruminant lambs. Aust. J. Agr. Res. 29:1263-1279.

Evans, E., J.G. Buchanan-Smith, and G.K. Macleod. 1975. Postprandial patterns of plasma glucose, insulin, and volatile fatty acids in ruminants fed low- and high-roughage diets. J. Anim. Sci. 41:1474-1479.

Fairbairn, J.W., and P.N.Șuwal. 1961. The alkaloids of Hemlock ( Conium maculatum L.)-II. Evidence for a rapid turnover of the major alkaloids. Phytochem. 1:38-46.

Forthman, Quick, D. 1984. Reduction of crop damage by olive baboons (Papio anubis): the feasibility of conditioned taste aversion. PhD. Diss., Univ. California, Los Angeles.
Fowler, M.E. 1983. Plant poisoning in free-living wild animals: a review. J. Wildl. Dis. 19:34-43

Freeland, W.J., and D.H. Janzen. 1974. Strategies in herbivory by mammals: the role of plant secondary compounds. Amer. Natur. 108:269-286.

Freeland, W.J., P.H. Calcott, and L.R. Anderson. 1985. Tannins and saponin: interaction in herbivore diets. Biochem. Syst. Ecol. 13:189-193.

Galef, B.G. Jr., 1985a. Direct and indirect behavioral pathways to the social transmission of food avoidance. p. 203-215. In: N.S. Braveman and $\mathbf{P}$. Bronstein (eds.), Experimental assessments and clinical applications of conditioned food aversions. New York Acad. Sci., New York.

Galef, B.G., Jr. 1985b. Socially induced diet preference can partially reverse a LiCl-induced diet aversion. Anim. Learn. Behav. 13:415-418.

Galef, B.G. Jr. 1986. Social interaction modifies learned aversions, sodium appetite, and both palatability and handling-time induced dietary preference in rats (Rattus norvegicus). J. Comp. Psychol. 4:432-439

Galef, B.G. Jr., and D.F. Sherry. 1973. Mother's milk: a medium for transmission of cues reflecting the flavor of mother's diet. J. Comp. Physiol. Psychol. 83:374-378.

Gamzu, E., G. Vincent, and E. Boff. 1985. A pharmacological perspective of drugs used in establishing conditioned food aversions. p. 231-249. In: N.S. Braveman and P. Bronstein (eds.), Experimental assessments and clinical applications of conditioned food aversions. New York Acad. Sci., New York.

Garcia, J. 1989. Food for Tolman: cognition and cathexis in concert. p. 45-85. In: T. Archer and L. Nilsson (eds.), Aversion, avoidance and anxiety. Hillsdale, N.J.

Garcia, J., and M.D. Holder. 1985. Time, space and value. Human Neurobiol. 4:81-89.

Garcia, J., F.R. Ervin, C.H. Yorke, and R.A. Koelling. 1967. Conditioning with delayed vitamin injections. Science 155:716-718.

Garcia, J., W.G. Hankins, and K.W. Rusiniak. 1974. Behavioral regulation of the milieu interne in man and rat. Science 185:824-831.

Garcia, J., K.W. Rusiniak, S.W. Kiefer, and F. Bermudez-Rattoni. 1982. The neural integration of feeding and drinking habits. p. 567-579. In: D.C. Woody (ed.), Conditioning: representation of involved neural functions. Plenum Press, New York.

Garcia, J., P.A. Lasiter, F. Bermudez-Rattoni, and D.A. Deems. 1985. A general theory of aversion learning. p. 8-21. In: N.S. Braveman and P. Bronstein (eds.), Experimental assessments and clinical applications of conditioned food aversions. New York Acad. Sci., New York.

Garcia y Robertson, R., and J. Garcia. 1987. Darwin was a learning theorist. p. 17-38. In: R.C. Bolles and M.D. Beecher (eds.), Evolution and learning. Lawrence Erlbaum Assoc. Inc., Hillsdale.

Goatcher, W.C., and D.C. Church. 1970a. Taste responses in ruminants. I. Reactions of sheep to sugars, saccharin, ethanol and salts. J. Anim. Sci. 30:777-790.

Goatcher, W.C., and D.C. Church. 1970b. Taste responses in ruminants. IV. Reaction of pygmy goats, normal goats, sheep and cattle to acetic acid and quinine hydrochloride. J. Anim. Sci. 31:373-382.

Grahame-Smith, D.G. 1986. The multiple causes of vomiting: is there a common mechanism? p. 1-8. In: C.J. Davis, C.V. Lake-Bakaar, and D.G. Grahame-Smith (eds.), Nausea and vomiting: mechanisms and treatment. Springer-Verlag, New York

Green, G.C., R.L. Elwin, B.E. Mottershead, and J.J. Lynch. 1984. Longterm effects of early experience to supplementary feeding in sheep. Proc. Aust. Soc. Anim. Prod. 15:373-375.

Green, K.F, and J. Garcia. 1971. Recuperation from illness: flavor enhancement in rats. Science 173:749-751.

Grovum, W.L., and H.W. Chapman. 1988. Factors affecting the voluntary intake of food by sheep. 4 . The effects of additives representing the primary tastes on sham intakes by oesophageal-fistulated sheep. Brit. J. Nutr. 59:63-72.

Hepper, P.G. 1988. Adaptive fetal learning: prenatal exposure to garlic affects postnatal preferences. Anim. Behav. 36:935-936.

Hepper, P.G. 1989. Foetal learning: implications for psychiatry? Brit. J. Psych. 155:289-293.

Hill, D.L., and P.R. Przekop, Jr. 1988. Influences of dietary sodium on functional taste receptor development: a sensitive period. Science 241:1826-1828.

Hill, D.L., and C.M. Mistretta. 1990. Developmental neurobiology of salt taste sensation. TINS 13:188-195.

Hinch, G.N., E. Lecrivain, J.J. Lynch, and R.L. Elwin. 1987. Changes in maternal-young associations with increasing age of lambs. Appl. Anim. Behav. Sci. 17:305-318.

Holder, M.D., and J. Garcia. 1978. Role of temporal order and odor intensity in taste-potentiated odor aversions. Behav. Neurosci. 101:158 -16.3. 
Hunter, R.F., and C. Milner. 1963. The behavior of individual, related and groups of south country Cheviot hill sheep. Anim. Behav. 11:507-513.

Johnson, A.E. 1974a. Predisposing influence of range plants on Tet radymia-related photosensitization in sheep: work of Drs. A.B. Clawson and W.T. Hoffman, Amer. J. Vet. Res. 35:1583-1585.

Johnson, A.E. 1974b. Experimental photosensitization and toxicity in sheep produced by Tetradymia glabrata. Can. J. Comp. Med. 38:406-410.

Jones, B.M. 1974. Circadian variation in the effect of alcohol on cognitive performance. Quart. J. Studies Alcohol. 35:1212-1224.

Jones, R.J., and R.G. Megarrity. 1983. Comparative toxicity responses of goats fed on Leucaena leucocephala in Australia and Hawaii. Aust. J. Agr. Res. 34:781-790.

Jones, R.J., and R.G. Megarrity. 1986. Successful transfer of DHPdegrading bacteria from Hawaiian goats to Australian ruminants to overcome the toxicity of leucaena. Aust. Vet. J. 63:259-262.

Keeler, R.F. 1984. Mammalian teratogenicity of steroidal alkaloids. p. 531-562. In: W.D. Nes, G. Fuller, and L. Tsai (eds.), Isopentenoids in plants. Marcel Dekker, New York.

Keeler, R.F. 1988. Livestock models of human birth defects, reviewed in relation to poisonous plants. J. Anim. Sci. 66:2414-2427.

Keeler, R.F., D.C. Baker, and J.O. Evans. 1988. Individual animal susceptibility and its relationship to induced adaptation or tolerance in sheep to Galea officinalis L. Vet. Hum. Toxicol, 30:420-423.

Keeler, R.F., D.C. Baker, and K.E. Panter. 1992. Comparison of the relative concentration of galegine in Verbesina enceliodes and Galega officinalis and the toxic and pathologic effects induced by them. $J$. Environ. Path. Toxic. Oncol. (In press).

Kellerman, T.S. 1987. Activated charcoal as prophylaxis against seneciosis. p. 70. In: Biennial Rep. Vet. Res. Inst., Onderstepoort, South Africa.

Key, C., and R.M. Maclver. 1980. The effects of maternal influences on sheep: breed differences in grazing, resting and courtship behavior. Appl. Anim. Ethol. 6:33-48.

Kosten, T., and R.J. Contreras. 1989. Deficits in conditioned heart and rate and taste aversion in area postrema-lesioned rats. Behav. Brain Res. 35:9-21.

Kuo, Z.Y. 1967. The dynamics of behavior development: an epigenetic view. Random House, New York.

Kupfermann, 1. 1985a. Hypothalamus and limbic system I: peptidergic neurons, homeostasis, and emotional behavior. p. 611-625. In: E.R. Kandel and J.H. Schwartz (eds.), Principles of neural science. Elsevier, New York.

Kupfermann, I. 1985b. Hypothalamus and limbic system II: motivation. p. 626-635. In: E.R. Kandel and J.H. Schwartz (eds.), Principles of neural science. Elsevier, New York.

Lane, M.A., M.A. Ralphs, J.D. Olsen, F.D. Provenza, and J.A. Pfister. 1990. Conditioned taste aversion: potential for reducing cattle loss to larkspur. J. Range Manage. 43:127-131.

Lett, B.T. 1985. The pain-like effect of gallamine and naloxone differs from sickness induced by lithium chloride. Behav. Neurosci. 99:145-150.

Lightfoot, L.O. 1980. Behavioral tolerance to low doses of alcohol in social drinkers. Ph.D. Diss., Waterloo Univ.

Lindroth, R.L. 1988. Adaptations of mammalian herbivores to plant chemical defenses. p. 415-445. In: K.D. Spencer (ed.), Chemical mediation of coevolution. Academic Press, New York.

Lynch, J.J. 1987. The transmission from generation to generation in sheep of the learned behavior for eating grain supplements. Aust. Vet. J. 64:291-292.

Lynch, J.J., R.G. Keogh, R.L. Elwin, G.C. Green, and B.E. Mottershead. 1983. Effects of early experience on the post-weaning acceptance of whole grain wheat by fine-wool Merino lambs. Anim. Prod. 36:175-183.

Mattock, A.R. 1985. Molecular basis of pyrrolizidine alkaloid toxicityrecent studies. p. 181-190. In: A.A. Seawright, M.P. Hegarty, L.F. James, and R.F. Keeler (eds.), Plant toxicology. Dominion Press, Melbourne.

Mehansho, A., A. Hagerman, S. Clements, L. Butler, J. Rogler, and D.M. Carlson. 1983. Modulation of proline-rich protein biosynthesis in rat parotid glands by sorghums with high tannin levels. Proc. Nat. Acad. Sci. USA 80:3948-3952.

Mehiel, R., and R.C. Bolles. 1984. Learned flavor preferences based on caloric outcome. Anim. Learn. Behav. 12:421-427.

Mehiel, R., and R.C. Bolles. 1988. Learned flavor preferences based on calories are independent of initial hedonic value. Anim. Learn. Behav. 16:383-387

Messier, C., and N.M. White. 1984. Contingent and non-contingent actions of sucrose and saccharine reinforcers: effects of taste preference and memory. Physiol. Behav. 32:195-203.
Milligan, L.P., W.L. Grovum, and A. Dobson (eds.). 1986. Control of digestion and metabolism in ruminants. Prentice-Hall, Englewood Cliffs.

Mirza, S.N., and F.D. Provenza. 1990. Preference of the mother affects selection and avoidance of foods by lambs differing in age. Appl. Anim. Behav. Sci. 28:255-263.

Mirza, S.N., and F.D. Provenza. 1991a. Effects of age and conditions of exposure on maternally mediated food selection in lambs. Appl. Anim. Behav. Sci. (In press).

Mirza, S.N., and F.D. Provenza. 1991b. Socially-induced food avoidance in lambs: direct or indirect maternal influence? Appl. Anim. Behav. Sci. (accepted).

Molina, J.C., H. Hoffman, L.P. Spear, and N.E. Spear. 1987. Sensorimotor maturation and alcohol responsiveness in rats prenatally exposed to alcohol during gestational day 8. Neurotoxicol. and Teratol. 9:121-128.

Morrill, J.L., and A.D. Dayton. 1978. Effect of feed flavor in milk and calf starter on feed consumption and growth. J. Diary Sci. 61:229-232.

Nolte, D.L., and F.D. Provenza. 1992. Food preferences in lambs after exposure to flavors in milk. Appl. Anim. Behav. Sci. 32:381-389.

Nolte, D.L., F.D. Provenza, and D.F. Balph. 1990. The establishment and persistence of food preferences in lambs exposed to selected foods. $J$. Anim. Sci. 68:998-1002.

Nolte, D.L., F.D. Provenza, R.L. Callan, and K.E. Panter. 1991. Food preferences in lambs after exposure to flavors in utero. Appl. Anim. Behav. Sci. (In press).

O'Dowd, D.J., and J.A. Edgar. 1989. Seasonal dynamics in the pyrrolizidine alkaloids of Heliotropium europaeum. Aust. J. Ecol. 14:95-105.

Oisen, J.D., and M.H. Ralphs. 1986. Feed aversion induced by intraruminal infusion with larkspur extract in cattle. Amer. J. Vet. Res. 47:1829-1833.

Panter, K.E., and L.F. James. 1990. Natural plant toxicants in milk: a review. J. Anim. Sci. 68:892-904.

Pavlov, I.P. 1927. Conditioned reflexes. Oxford Univ. Press, London.

Pelchat, M.L., H.J. Grill, P. Rozin, and J. Jacobs. 1983. Quality of acquired responses to tastes by Rattus norvegicus depends on type of associated discomfort. J. Comp. Physiol. Psychol. 97:140-153.

Pfister, J.A., M.H. Ralphs, and G.D. Manners. 1988a. Cattle grazing tall larkspur on Utah mountain rangeland. J. Range Manage. 41:118-122.

Pfister, J.A., G.D. Manners, M.H. Ralphs, Z.X. Hong, and M.A. Lane. 1988b. Effects of phenoloy, site and rumen fill on tall larkspur consumption by cattle. J. Range Manage. 41:509-514.

Pfister, J.A., D.C. Adams, M.J. Arambel, J.D. Olsen, and L.F. James. 1989. Sublethal doses of toxic larkspur: effects on intake and rumen dynamics in cattle. Nutr. Rep. Inter. 40:629-636.

Prister, J.A., F.D. Provenza, and G.D. Manners. 1990. Ingestion of tall larkspur by cattle: separating the effects of flavor from post-ingestive consequences. J. Chem. Ecol. 16:1697-1705.

Pfister, J.A., C.D. Cheney, and F.D. Provenza. 1992. Behavioral toxicology of livestock ingesting plant toxins. J. Range Manage. (In press).

Provenza, F.D., and J.C. Malechek. 1984. Diet selection by domestic goats in relation to blackbrush twig chemistry. J. Appl. Ecol. 21:831-841.

Provenza, F.D., and D.F. Balph. 1987. Diet learning by domestic ruminants: theory, evidence and practical implications. Appl. Anim. Behav. Sci. 18:211-232.

Provenza, F.D., and D.F. Balph. 1988. The development of dietary choice in livestock on rangelands and its implications for management. J. Anim. Sci. 66:2356-2368.

Provenza, F.D., and D.F. Balph. 1990. Applicability of five diet-selection models to various foraging challenges ruminants encounter. p. 423-459. In: R.N. Hughes (ed.), Behavioral mechanisms of food selection. NATO ASI Series G: Ecological sciences, Vol. 20. Springer-Verlag, Heidelberg, New York.

Provenza, F.D., and E.A. Burritt. 1991. Socially-induced diet preference ameliorates conditioned food aversion in lambs. Appl. Anim. Behav. Sci. 31:229-236.

Provenza, F.D., J.E. Bowns, P.J. Urness, J.C. Malechek, and J.E. Butcher, 1983. Biological manipulation of blackbrush by goat browsing. J. Range Manage. 36:513-518.

Provenza, F.D., D.F. Balph, J.D. Olsen, D.D. Dwyer, M.H. Ralphs, and J.A. Pfister. 1988. Toward understanding the behavioral responses of livestock to poisonous plants. p. 407-424. In: L.F. James, M.H. Ralphs, and D.B. Nielsen (eds.), The ecology and economic impact of poisonous plants on livestock production. Westview Press, Boulder.

Provenza, F.D., E.A. Burritt, T.P. Clausen, J.P. Bryant, P.B. Reichardt, and R.A. Distel. 1990. Conditioned flavor aversion: a mechanism for goats to avoid condensed tannins in blackbrush. Amer. Natur. 136:810-828. 
Ralphs, M.H., and J.D. Olsen. 1990. Adverse influence of social facilitation and learning context in training cattle to avoid eating larkspur. J. Anim. Sci. 68:1944-1952.

Riley, A.L., and D.L. Tuck. 1985. Conditioned taste aversions: a behavioral index of toxicity. p. 272-292. In: N.S. Braveman and P. Bronstein (eds.), Experimental assessments and clinical applications of conditioned food aversions. New York Acad. Sci., New York.

Riopelle, R.J., K.L. Stevens, and P.B. Little. 1991. Neurotoxicity of sesquiterpene lactones. p. 298-303. In: L.F. James, R.F. Keeler, E.M. Bailey, P.R. Cheeke, and M.P. Hegarty (eds.), Poisonous plants. Iowa State Univ. Press, Ames.

Roath, L.R., and W.C. Krueger. 1982. Cattle grazing and behavior on forested range. J. Range Manage. 35:332-338.

Robbins, C.T., S. Mole, A.E. Hagerman, and T.A. Hanley. 1987. Role of tannins in defending plants against ruminants: reduction in dry matter digestion? Ecology 68:1606-1615.

Rogers, Q.R., and A.R. Egan. 1975. Effects of amino acid imbalance in liquid fed lambs. Aust. J. Biol. Sci. 28:169-181.

Roll, D.L., and J.C. Smith. 1972. Conditioned taste aversion in anesthetized rats. p. 98-102. In: M.E.P. Seligman and J.L. Hager (eds.), Biological boundaries of learning. Appleton-Century-Crofts, New York.

Roxin, P. 1976. The selection of foods by rats, humans and other animals. p. 21-76. In: J.S. Rosenblatt, R.A. Hinde, E. Shaw, and C. Beer (eds.), Advances in the study of behavior. Academic Press, New York.

Rusiniak, K.W., W.G. Hankins, J. Garcia, and L.P. Brett. 1979. Flavorillness aversions: potentiation of odor by taste in rats. Behav. Neuro. Biol. 25:1-17.

Rusiniak, K.W., C.C. Palmerino, A.G. Rice, D.L. Forthman, and J. Garcia . 1982. Flavor-illness aversions: potentiation of odor by taste with toxin but not shock in rats. J. Comp. Physiol. Psychol. 96:527-529.

Schulte-Herman, R. 1979. Reactions of the liver to injury: adaptation. p. 385-444. In: E. Farber and M.M. Fisher (eds.), Toxic injury of the liver, Part A. Marcel Dekker, New York.

Shapiro, A.P., and P.E. Nathan. 1986. Human tolerance to alcohol: the role of Pavlovian conditioning processes. Psychopharmacology 88:90-95.

Sherman, J.E., C.F. Hickis, A.G. Rice, K.W. Rusiniak, and J. Garcia. 1983. Preferences and aversions for stimuli paired with ethanol in hungry rats. Anim. Learn. Behav. 11:101-106.

Siegel, S. 1975. Evidence from rats that morphine tolerance is a learned response. J. Comp. Physiol. Psychol. 89:498-506.

Siegel, S., and D.W. Ellsworth. 1986. Pavlovian conditioning and death from apparent overdose from medically prescribed morphine: a case report. Bull. Psychomom Soc. 24:278-280.

Siegel, S., and K. Sdno-Jarvie. 1986. Attenuation of ethanol tolerance by a novel stimulus. Psychopharmcology 88:258-261.

Siegel, S., R.E. Hinson, M.D. Krank, and J. McCully. 1982. Heroine "overdose" death: Contribution of drug-associated environmental cues. Science 216:436-437.

Simbayi, L.C., R.A. Boakes, and M.J. Burton. 1986. Can rats learn to associate a flavour with the delayed delivery of food? Appetite 7:41-53.

Smith, G.S. 1986. Gastrointestinal toxifications and detoxifications in ruminants in relation to resource management. p. 514-542. In: K. Rozman and $O$. Hanninen (eds.), Gastrointestinal toxicology. Elsevier, New York.

Smith, G.S. 1992. Toxification and detoxification of plant compounds by ruminants. J. Range Manage. 45:25-30.
Smotherman, W.P. 1982. Odor aversion learning by the rat fetus. Physiol. Behav. 29:769-771.

Smothermen, W.P., and S.R. Robinson. 1987. Prenatal influences on development: behavior is not a trivial aspect of fetal life. Develop. Behav. Pediat. 8:171-175.

Squibb, R.C., F.B. Provenza, and D.F. Balph. 1990. Effect of age of exposure on consumption of a shrub by sheep. J. Anim. Sci. 68:987-997.

Stickrod, G., D.P. Kimble, and W.P. Smotherman. 1982. In utero taste/ odor aversion condition in the rat. Physiol. Behav. 28:5-7.

Strydom, J.A., and J.P.J. Joubert. 1983. The effect of pre-dosing Homeria pallida Bak. to cattle to prevent poisoning. J.S. Afr. Vet. Assoc. 54:201-203.

Thorhallsdottir, A.G., F.D. Provenza, and D.F. Balph. 1987. Food aversion learning in lambs with or without a mother: discrimination, novelty and persistence. Appl. Anim. Behav. Sci. 18:327-340.

Thorhallsdottir, A.G., F.D. Provenza, and D.F. Balph. 1990a. Ability of lambs to learn about novel foods while observing or participating with social models. Appl. Anim. Behav. Sci. 25:25-33.

Thorhallsdottir, A.G., F.D. Provenza, and D.F. Balph. 1990b. The role of the mother in the intake of harmful foods by lambs. Appl. Anim. Behav. Sci. 25:35-44.

Thorhallsdottir, A.G., F.D. Provenza, and D.F. Balph. 1990c. Social influences on conditioned food aversions in sheep. Appl. Anim. Behav. Sci. 25:45-50.

Thye, F.W., R.G. Warner, and P.D. Miller. 1970. Relationship of various blood metabolites to voluntary forage intake in lactating ewes. J. Nutr. 100:565-572.

Toppel, G., L. Witte, and T. Hartmann. 1988. N-oxidation and degradation for pyrrolizidine alkaloids during germination of Crotalaria scassellatti. Phytochem. 27:3757-3760.

Tordorr, M.G., and M.I. Friedman. 1989. Drinking saccharin increases food intake and preference-IV. Cephalic phase and metabolic factors. Appetite 12:37-56.

Wade, A.E., J.E. Holl, C.C. Hilliard, E. Molton, and F.E. Greene. 1968. Alteration of drug metabolism in rats and mice by an environment of cedar wood. Pharmacology 1:317-328.

Wattenburg, L.W., W.D. Loub, L.K. Lam, and J.L. Speier. 1976. Dietary constituents altering the reponses to chemical carcinogens. Fed. Proc. 35:1327-1331.

Weiss, B. 1986. Emerging challenges to behavioral toxicology. p. 1-20. In: Z. Annau (ed.) Neurobehavioral toxicology. Johns Hopkins Univ. Press, Baltimore.

Westoby, M. 1974. An analysis of diet selection by large generalist herbivores. Amer. Natur. 108:290-304.

Westoby, M. 1978. What are the biological bases of varied diets? Amer. Natur. 112:627-631.

Williams, M.C. 1989. Toxicological investigations on Toano, Wasatch, and stinking milkvetches. J. Range Manage. 42:366-367.

Zahorik, D.M., and K.A. Houpt. 1977. The concept of nutritional wisdom: applicability of laboratory lerning models to large herbivores. p. 45-67. In: L.M. Barker, M. Best, and M. Domjan (eds.), Learning mechanisms in food selection. Baylor Univ. Press, Waco.

Zahorik, D.M., and K.A. Houpt. 1981. Species differnces in feeding strategies, food hazards, and the ablity to learn food aversions. p. 289-310. In: A.C. Kamil and T.D. Sargent (eds.), Foraging behavior. Garland, New York.

Zahorik, D.M., S.F. Maier, and R.W. Pies. 1974. Preferences for tastes paired with recovery from thiamine deficiency in rats: appetitive conditioning or learned safety? J. Comp. Physiol. Psychol. 87:1083-1091. 